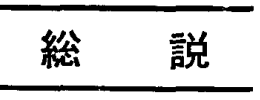

\title{
フィラリア伝播効率に及ぼす媒介蚊の要因
}

\author{
栗 原 毅 前田龍一郎

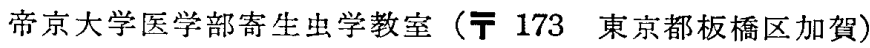

（受領：1980年 8 月 6 日）

\section{Entomological factors affecting the transmission of mosquito-borne filariasis}

\author{
Takeshi KURIHARA and Ryuichiro MAEDA \\ Department of Parasitology, Teikyo University School of Medicine, \\ Itabashi, Tokyo 173, Japan
}

\begin{abstract}
蚊が媒介するフィラリア病に関して，二つの意図をも ってこの総説を作製した，第一はスナネズミ，マレー米 状虫などを用いたフィラリアの動物実験系の維持のうえ で，より能率よく伝播を成立させていくためには, 終宿 主のミクロフィラリア密度, 蚊のとりこみ数, 蚊の生存 率などを考えて，どのような状況下で蚊の吸血・飼育を させたらよいか. 第二は，これを逆用して，フィラリア 病流行地域で伝播の実態を監視したり, 流行阻止作業を 進めるらえで，昆虫学的な重要点が何であるか，が浮か び上がらないか。
\end{abstract}

周知のように，フィラリア仔虫は媒介蚊の体内では， 仔虫数が減少することはあっても増殖はしない，したが って能率よい伝播とは媒介蚊群になるべく多数のミクロ フィラリアをとりこませ，かつ最低の減少度のレベルを 求めて適用することになる。蚊体内での仔虫の生活史 を, そのポピュレーションの変動といら面から, 従来の 知見を整理してみた。

また予防と伝播阻止を主軸とする本病の対策におい て,流行地では伝播の状況を把握していることが,媒介昆 虫の担当者にとって重要な業務となる。伝播の強さ,その 季節的な変化, 集団駆虫の効果判定などを客観的に, 伝 播状況の変化という面からとらえるのにはどのような要 因をおさえ扎ばよいか。 これらの要因を数量的に表現す ることができないか，こうした流行地での実務面をも考 慮して，伝播についての検討をも加えた。

なお本文では，蚊媒介のヒト・フィラリア病を主体と し, 次の略称を用いている.
W. b. : Wuchereria bancrofti

B. m. : Brugia malayi

B. p. : Brugia pahangi

$\mathrm{Mf} \quad$ : ミクロフィラリア

\section{1. 蚊の Mf とりこみ}

\section{a. とりこみ数と期待値}

宿主のもつ Mf 密度が高くなると, 吸血蚊の中腸内 に Mf が見いだされる蚊の比率（Mf とりこみ率）は， 相対的に高くなり，密度が $5 / \mathrm{mm}^{3}$ を越すと $100 \%$ に達す る (Jordan and Goatly，1962)，あるいは，とりこみ 率 $y$ と Mf 密度 $x$ に $y=41.654 x+48.735$ の関倸が ある(山本，1964)，といら報告が知られている。また蚊 にとりこまれる Mf の数も，高密度であるほど，多数 になり，Jordan and Goatly（1962）では，両者の相関 係数が0.9と著しく高い. しかし，蚊がとりこんだ Mf 数を, 宿主 (吸血源) の Mf 密度から推測することは, 意外飞難しい，従来，吸血蚊の吸血量を測定して，宿主 の Mf 密度から換算し期待値として算出され，実際に とりこんだ Mf 数 (実測值) と比較して, 多くの討議 がなされてきた。

Hawking and Worms (1961) は, 従前の感染実験を 総説して「Mf とりこみ数にはバラッキが大きいが，一 般的には宿主の Mf 密度からの期待值より少ない。し かし， $0.2 / \mathrm{mm}^{3}$ といった低密度宿主からの吸血とりこ みでは，ほぼ期待值どおりの Mf 数をとりこむ」と記 している. Kershaw ら (1953) が，すでにこの状況を 
子細に観察しているが，最近では Gubler ら (1973) が，ほぼこの見解に沿った成績をえた. しかし，この成 績（W．b.）は，同一人から同時刻に吸血したとは思え ない程にとりこみ数の変異幅が大きい. 平均值に換算す ると宿主の Mf 密度が $10 / \mathrm{mm}^{3}$ 以上では期待値より少 ない，それ以下ではほぼ期待値どおりといら結果になっ た. また Obiamiwe (1977b) は，血液を薄膜を通して 蚊に吸わせたが, Mf (B. p.) とりこみ数の平均值は, Mf 密度相応に上下するがどれも期待值のだいたい $1 / 3$ の值であった. 1 回に 10 匹前後の蚊を供し 21 群試みた が，期待值以上とりこんだ群はなかった。これらはいわ ば，「過少とりこみ説」をしめした例といえよう。

これに対し，吸血蚊の Mf とりこみが，期待值をは るかに上まわり，蚊が Mf を選択的にとりこんでいる 上らな印象を与える，いわば過剩とりこみ説の実験例が ある。Ramachandran (1966) は，ネッタイシマカをネ コ (B. m.) から吸血させた 3 グループのいずれもが, 3 匹のネコそれぞれの Mf 密度から算出した期待值を, 3 倍以上も上まわる成績をえた。57匹中 6 匹の蚊が期待 值を下まわったのみで，中には10倍以上とりこむ蚊むい た. 近年, 滤過膜濃縮法などの導入で, 超低密度の Mf 保有者の存在が知られ，その保虫者が伝播に関与するか 否か, 疫学的意義が問われるようになって, 低密度保虫 者からの過剩とりこみ説が，注目をあびるようになっ た.

Bryan and Southgate (1976) は, $0.01 / \mathrm{mm}^{3}$ という 低密度 Mf 保虫者 (W. b.) からの吸血で，670匹の蚊 が, $7.2 \sim 11.8 \%$ の感染率を示し, 計80匹のフィラリア 仔虫を回収した，中には 2 匹の仔虫をとりこんだ蚊もい た. 吸血量 $1.3 \mathrm{mg}$ で, 回收の期待值は合計 $5 \sim 6$ 匹と 算出されていたので15倍もとりこんだことになる。 また Carme and Laigret (1979) は，度々の多量採血の検查 でも遂に Mf を証明しえなかった人に, Aedes polynesiensis 室内育成蚊100匹を吸血させたところ，そのう ち 1 匹から 5 匹のIII期仔虫を回収して xenodiagnosis に成功した.

過少，過剩の二つのあい反する見解を支持する報告は 他にもある. しかし子細に検查するとどちらともいえな いデータも多い. Ramachandran and Zaini (1967) は, トウゴウヤブカ63匹をネコ（B. m.）から吸血させて, 過少とりこみだったとしているが，吸血蚊の合計とりこ み Mf 数は1,096, 期待值の合計は759.9である. 4 段階 の Mf 密度吸血源を供しているが，明らかに期待值以 下だったのは， $7.28 / \mathrm{mm}^{3}$ という最高密度の吸血群だけ であった. また, Obiamiwe (1977b) は, Jordan and Goatly（1962）の成績を, 過剩とりこみ説に採用してい
るが，原著者らは「一見過剩にとりこんでいるが，これ はほんの数匹の蚊が800以上もの Mf をとりこんだため で，期待值以上あるいは以下の Mf をとりこんだ蚊の 個体数の差異は統計的に有意なものではない，過剩とり こみの証拠はない」と記している。この実験は W.b.一 ネッタイイエカによって行われている.

過剩とりこみは, Ramachandran (1966) 以外では, Mf の著しい低密度の際にみられるようであるが, 低密 度ゆえに必ず起こる現象ではない，山本（1964）の成績 (W. b.) は，34組の蚊の感染実験で 7 組を除き期待值に は達していないと推定されるが， $0.06 \sim 1.0 / \mathrm{mm}^{3}$ とい った低密度でも期待値以下であった。 Ramachandran and Zaini (1968) も0.017/ $/ \mathrm{mm}^{3}$ (B. m.) で, Mf とり こみ蚊を見いだしていない. Samarawickrema ら (1979) は，同じ西サモアで， Bryan and Southgate の成績の 追試をしているが，同じ Ae. polynesiensis で，30回の テスト中，25例が期待值より多い結果であった．しかし せいぜい 2 倍程度のとりこみで， $0.02 / \mathrm{mm}^{3}$ 以下の低密 度がとくに過剩にとりこんだこともなかった. Ae. samoanus も供したが, やはり1.3〜1.5倍のとりこみに なった.

\section{b. とりこみ数変動の諸要因}

Mf とりこみ数は, 期待值と一致するのではないか, と考えさせるデータも多い, 大森 (1958) (W. b.) は, 467匹の吸血アカイエカ中 $47.9 \%$ が期待值より少なく, $52.1 \%$ が余計にとりこんだ, そしてその分布様式は明ら 加集中型を示し, 蚊法個体別に吸血か所の Mf 密度 を反映したとりこみをしていると考えている. Ramachandran and Zaini (1967) の報告も蚊を個体別にみ机 ば， $57.1 \%$ の蚊が期待值より少なく，残りは同等かまた は過剩にとりこんでいるし，Wharton (1957a) (B. m.) は, とりこみ $\mathrm{Mf}$ 数平均值は期待值の1.5倍だが， 40 匹中23匹 (57.5\%) が，期待值を下まわった. Pacheco ら (1972) は, Dipetalonema viteae の Mfをとりこ んだマダニで, とりこみ数は個々一様ではなく, 過剩, 過少あるが，これらの回帰直線を求めると，期待值とよ く一致すると報告している.

とりこんだ Mf 数の分布様式が集中型を呈すること については, その後, 田中ら (1963) がコトンラットと イエダニ, Schmid and Robinson (1972) はムクドリ の Mf をとりこんだヌカカ，また和田ら（1977）はマ レー系状虫とトウゴウヤブカなどの組みあわせで検討さ れ，いずれも負の二項分布に一致するとされている。し たがって, Mf とりこみ数の平均值算出は, 十分なサン プル数がないと, 期待值との大少判定に結論を誤ること になろら。 
過剰あるいは過少とりこみを経験した多くの実験者 は，Mf とりこみにさいしての機構について種々の考察 を加えている．過剩とりこみを再現した著者らは，一様 に，蚊の吻端には Mf を集中する，あるいは，Mf に は口吻に誘引される機能があるのではないかと考えてい る. Obiamiwe (1977b) は,この誘引の能力が, B. m. と W. b. とでは異なっているのではないか, と考え, Ramachandran and Zaini (1968) は，蚊の種によって とりこみのマナーが違ら，と考えた．前述の大森(1958) の報告を，トウゴウヤブカで追試した中村（1964）は， この蚊では，期待值の $1 / 5 \sim 1 / 2$ であると報告した。しか し同じトウゴウヤブカでも和田ら (1977) は，ネコ（B. m.）加吸血した台北産の蚊は期待値より多く，三崎産 のコロニーは少なくとりこんだ，ということからとりこ み数の大少は種特有の現象とはいえない。

蚊個体ごとの吸血量の差異が，とりこみ Mf 数の差 異となって表現されることは考えられることだ.しかし 吸血量を測定した往来の報告は例外なく，吸血量ととり こみ Mf 数の間に正の相関はなかったと結論している. ただし従来の研究の多くは, 吸血量を, 吸血前後の体重 の差によって，しかも数匹以上の蚊をプールして扱い， その平均值によって個体の吸血量とし，Mf 数は一匹ご との中腸内から, 塗抹標本によって測定しているので, 必ずしも厳密に検討された值ではない. 前田・栗原 $(1980$ a,b) は，Briegel b（1979）の個体別吸血量測定法と 濾過膜利用の Mf 分離法を組み合わせて, 個々の蚊の 両者の数值を測定した. この結果は, 同時の吸血でも， Mf とりこみ数が，1から70までふれ，吸血量は $2 \sim 8$ $\mathrm{mm}^{3}$ とばらついた，吸血量の多い蚊が多数の Mfをと りこんでいる傾向は認められるが，両者の相関係数は +0.5であった. そしてどの蚊も期待值よりは少なく $\mathrm{Mf}$ をとりこんでいた.

この奏験ではさらに，同一飼育歷の同じ群のトウゴウ ヤブカで, 羽化後 5 日と 12 日の吸血を比較したところ, 5 日の方が吸血量, Mf 数とも，はるかに多加たた。 れもとくに Mf のとりこみ数が多いのが顕著であった ことから，とりこみ数の多少に影響する要因はかなり複 雑と思われる.

過少とりこみの原因を, 吸血蚊が吸血中または, 直後 に肛門から排浛液とともに Mf を出してしまらからと いう考えもある. しかし，Jordan and Goatly (1962)， 山本（1964）とも，排液中の Mf 数は著しく少数であ ると報告している。 また，吸血中に頭部の cibarial armature と, pharyngeal armature の 2 か所のネックを 血液とともに通過するさいに Mf が傷つけられ行動力を 失い, 中腸内でのカウントに入らないことも考えられる
(Coluzzi and Trabucchi, 1968 ; McGreevy $ら, 1978$ ). この歯状機構は，どの蚊種にも備わるものではなく， Bryan ら (1974a, b) は, ネッタイシマカは cibarial を欠き, An. gambiae は両方ともあるため, 中鹃内の Mf 数で前者は15\%，後者は $80 \%$ が破損していた々い う. Omar and Zielke (1978) は，ここで破損をなねが れた Mf は, An. gambiae 体内で, 以後きわ放て高い 生存率を保つという。

これに対して過剰とりこみ現象を説明することは難し い. Wharton (1957a) の Mansonia による B. m. と りこみは平均1.5倍過剩とりこみであったが，彼はこの 原因を「吸血後の蚊の体重測定が，それ以前の蚊の排渄 液の重量を考慮に入れなかったため，過少に評洒さ机期 待值を低めに計算した」と考えている。このほかに, Denham ら (1971), 和田ら (1977) が, 塗抹した Mf がスライドグラス上を離脱する在険性も指摘している。

最も基本的には終宿主の Mf 密度は, 蚊の吸血方所 のどこでも同一值を示すか, といら点がある。 Burren (1972) はネコ (B. m.) の左右の耳から6サンプルーうつ 採血し, 密度平均值は左右とも等しいが, サンプル中の最 大值は最小值の 2 3 倍にもなること, Nathan and Rac. curt（1979） は人耳たぶからの採血（W.b.）が指端の 採血の Mf 密度の 4 倍以上で有意な差異のあることを 報告している。 しかし Gubler ら（1973）瀞脈採血 でも末梢血採取でも Mf 密度に変化はなかったとし， 和田ら (1977) は, 同一宿主, 同一か所の Mf 密度分 布はポアソンと一致した, という報告もあるので，合後 の検討課題といえよう.

\section{2. 蚊体内での仔虫数の減少}

\section{a. 実験感染指数}

ある吸血蚊群がとりこんだ Mf が，而期に達するま で, 生存していた蚊だけを対象にして，而期保有率= infective rate; mature larva rate; 完熟幼虫保有率 (山本, 1964), あるいはIII期仔虫保有数 (mature larva density）を求めるのは，乙ばしば採集蚊の解剖成績の 説明に用いられる。これを前述来の諸感染実験に適用寸 ると，III期保有率は，吸血源の Mf 密度が高いときは， 高率になる傾向が強いが，100\%を示すことは少ない.

山本 (1964) は, 保有率と, Mf 密度との間に直線回帰 式を算出したが，100\%に達するのは $100 / \mathrm{mm}^{3}$ 以上とい う高密度の Mf をとりこむ場合となった。

一方，生存蚊の川期保有数平均值については多くが， ある Mf 密度で, 頭うちの值を示している, その值は Jordan and Goatly (1962) (W. b. ネッタイイエカ) では密度 $6.5 / \mathrm{mm}^{3}$ で7.2匹；山本 (1964) $9.4 / \mathrm{mm}^{3}$ で 
7.5匹（W．ｂ.ネッタイイエカ）; Ramachandran and Zaini (1968)（B. m. トウゴウヤブカ） 6 7/ $\mathrm{mm}^{3}$ で15 匹; Obiamiwe (1977b) (B. p. アカイエカ) $13 / \mathrm{mm}^{3}$ で 5.1 匹といった值である. これ以上高密度の Mfをと りこんでもIII期仔虫数の平均值はふえないという域值で ある. Pacheco ら (1972) は, Dipetalonema で上限值 が20〜30の頭うちを描く曲線で示している.

このような実験感染の効率を，蚊種間等で比較をする ために, Kartman (1954) は, Index of experimental infection=実験感染指数（山本，1964）を提示した.こ れは（a）吸血した蚊の生存率，（b）生存蚊のIII期仔虫 保有率, (c) Host Efficiency Ratio (HER) として, III期仔虫の生存蚊あたり平均保有数/Mf とりこみ数の平 均值, 三つの積である. その後 Wharton (1957a) は, III期仔虫総回收数/吸血蚊総数で指数をあらわし，また WHO (1962) は, Wharton の式を吸血源密度で割っ た值を提示した，山本（1964）は，Kartman の式を用 い, $\mathrm{Mf}$ 密度 $1 \sim 2 / \mathrm{mm}^{3}$ (とりこみ数 3.3 ）のとき， 0.55 で最大值をえた。また Jordan and Goatly (1962) も， ほぼ同じ結果をえたが，Wharton の式では，Mf 密度 の差異は，指数としては大きな影響を示さなかった，と している.これらの指数は，相対的に効率を示すため尺 度が異なり，表 1 にみるように，同一データでも異なっ た傾向を示している.

Mansonia 属の蚊が B. m. に高い HER 值をもつこ とが知られている (Wharton, 1957a, b) . 0.9 10.2/ $\mathrm{mm}^{3}$ の密度の Mf とりこみ蚊の10.5日後の死亡率が $3 \sim 14$ \%，生存蚊は，とりこみ数とほぼ同じ4.1〜47.9の而期 をもつ。しかし Mf 密度23.6という高密度では低下し 10匹程度のIII期仔虫保有になるので，やはり頭うちの状 況だが，域值はきわめて高い。この属の特異な Mf 親 和性は B. patei とりこみでも見られ，M. uniformis は, 平均 16.5 , 最大值58の Mf をとりこみ, その $98 \%$ が胸筋に入り，半数の蚊が 20 匹上（最大 69 匹）のIII期 を保有した (Laurence and Pester, 1961).

\section{b. 減少の要因}

蚊の中腸内にとりこまれた Mf は，中腸壁を貫通脱 出し，胸筋へ移行寸る。ここで発育して，而期仔虫に育 ち，終宿主へ感染をする，この間流行地では，10〜15日 を要しているが，とりこまれた仔虫の全部が生長を全う するわけではない. Pichon ら (1974) は,「Mf とりこ み数がある域值を越すと, parasite yield（蚊群がとり こんだ Mf 総数とM期に育った仔虫数の比）は相対的 に低下してIII期数がある頭らちになる場合と,逆にyield が高まり，多数の而期仔虫を育てる場合があり」このち がいは，蚊の種の違いで生じるとしている。この para- site yield は，とりこんだ Mf が，而期にまで育つ間 の生存率と同じであり，前述の Kartman の HER の 值と吸血蚊の生存率を乗じた数值でも示される。

仔虫の生存率を左右する要因の一つは，仔虫の死であ る. その時期は，中腸内から脱出できずに Mfのまま 死んでしまう初期死亡，体腔または胸筋内で成育中に死 ぬ中期死亡，および亚期に育っても宿主体内に入れず死 ぬ後期の死亡と，仮に三大別されよう，蚊の種によって この時期のいつが仔虫の死を多くもたらすか特徴的で, 非感受性 (B. p.) のアカイエカ群にとりこまれた Mf は，99\%が中腸内で死ぬが，ネッタイシマカでは胸筋内 での中期死亡率が高い（Obiamiwe，1977a).

'仔虫の中腸壁貫通は, 吸血の直後から見られ，5１5 分ほどが最盛期となる (Esslinger, 1962). したがって 吸血後数時間以内に脱出できなかった Mf は，固まり かけた血液の中で行動力を失ってしまう（Ramachandran, 1966). Ae. scutellaris グループの蚊は，3 時間 以内にとりこんだ蚊体内 Mf (B. p.) の95\%が，中腸脱 出に成功し, 非感受性では, 1.5 時間以内に $50 \%$ が脱出す るので，感受性の区別規準とされている (Owen, 1978). 済州島の B. m. は，オオクロヤブカにとりこまれた場 合，胸筋に移行して直後に死に，ヒトスジシマカではさ らに後に死ぬ(Oda and Wada, 1980). またネッタイシ マカの非感受性系統は, 大部分の仔虫が，胸部侵入後に 死ぬ(Omar and Zielke, 1978)。しかし感受性蚊群でも 前項の諸実験の示すように，とりこみ Mf 数が著しく多 いと密度効果が作用して仔虫の死が起こると思われる.

減少の要因の第二に, 仔虫を蔵している蚊の死に附随 して起こる減少がある. これもとりこみ初期と, 仔虫が 発育して後の時期にみられるケースがある。しかし，カ エルを吸血してそのフィラリア Foleyelle flexicanda の Mfをとりこんだ Ae. triseriatus が, Mf 密度の高 低にかかわりなく，吸血後 1〜2時間で $100 \%$ 死んでし まう(Benach and Crans, 1975) という極端な例を除い て，一般には蚊の飼育といら不安定な条件が含まれてい るため，仔虫をとりこんでいるために死んだか否か判定 の難しいケースも多い. Rosen (1955) はタヒチで, Ae. polynesiensis が, Mf (W. b.) の宿主密度 $9.78 / \mathrm{mm}^{3}$ までは，蚊の生死に影響がないと報告したが，西午ア での実験（Samarawickrema ら，1979）では密度0.1以 下と，0.1 0.99/ $\mathrm{mm}^{3}$ では，おのおの蚊の生存率 $22 \%$ ， それが，1.0〜5.29だと $10.4 \%$ に低下した.ここでもや はり，とりこんだ Mf の密度が蚊の生死に影響する。 後に Christensen (1978) は, 宿主 Mf (Dirofilaria immitus）密度と蚊の死亡率との間には，明らかな負の 相関を見いだした。蚊の死も仔虫の密度効果のあらわれ 
表 1 Index of Experimental Infection の計算例(前田・栗原, 1980aによる)

\begin{tabular}{|c|c|c|}
\hline 吸血時日令 & 5 日 & 12 日 \\
\hline 吸血蚊数 & 188 & 186 \\
\hline Mf とりこみ総数* & $3,741(19.9)$ & $2,585(13.9)$ \\
\hline 14 日後生存蚊数 $<$ 生存率 $>$ & $85<45.2 \%>$ & $47<25.2 \%>$ \\
\hline III期保有蚊数＜感染率＞ & $45<52.9 \%>$ & $32<68.0 \%>$ \\
\hline III期仔虫回収総数 & $227(2.67)$ & $151(3.21)$ \\
\hline \multicolumn{3}{|l|}{ 算出值 } \\
\hline HER 值 & 0.134 & 0.231 \\
\hline Kartman's index & 0.0321 & 0.0397 \\
\hline Wharton's index & 1.207 & 0.811 \\
\hline WHO's index & 0.086 & 0.057 \\
\hline Parasite yield & 0.0606 & 0.0584 \\
\hline
\end{tabular}

* 推定值

（）1 蚊忍たり平均值

であろう。

前田・栗原(1980a) は，同一宿主 (B. m.) から羽化 後 5 日と 12 日の 2 群の蚊に吸血させた。表 1 はその成績 だが,HER と Kartman の index 法者が高く,他は 逆になる. parasite yield は, この点, Mf の生存率と して素直な表現ともいえる。この表のようにとりこみ全 数の $94 \%$ 再群ともに生長しなかったのだが， 5 日群で は55\%の Mf が，12日では75\%が，蚊の死によって失 われたと推察しらる。従来の多くの感染実験でも yield 值は低く，宿主 $\mathrm{Mf}$ 密度が $5 / \mathrm{mm}^{3}$ のときとりこみ $\mathrm{Mf}$ は, Jordan and Goatly (1962) (W. b. ネッタイイエ カ) $10 \%$ 以下, Ramachandran (1966) (B. m. ネッタイ シマカ） 7 〜 \%に減る.そして一般に宿主の Mf 密 度が高まるほどに yield が低下寸る，さらにその低下 の主な原因として蚊の死の要因の占める割り合いが強く なってくる，ただしその割り合いは，個々の実験（蚊の 飼育維持法も関連して）によりまちまちで，宿主密度 $5 / \mathrm{mm}^{3}$ 程度で Jordan and Goatly は, yield 低下の 7 〜 8\%は蚊の死に依存するとし，同様に山本（1964）は 65\% (W.b. ネッタイイエカ), Ramachandran (1966) は21\%, Samarawickrema ら (1979) は88\% (W. b. Ae. polynesiensis) と，大きく異なる. Wharton (1957b) の 効率よい感染では $10.2 / \mathrm{mm}^{3}$ 以下では yield $0.7,10 \%$ が蚊の死により，また $23.6 / \mathrm{mm}^{3}$ という高密度で yield 0.2 , うち,蚊の死により $60 \%$ が失われている.Mansonia の例を除き，多くの感染実験で, yield が10\%以下と低 率であることは，野外ではさらに低くなるであろうこと を子想せしめる。

これに対して，Mf 密度が高まると逆に yield が増加 するという例が, An. gambiae で示されている. Mf
(W. b.）とりこみ数 1 ～70の範囲では，少数とりこみ だとその $20 \%$ 以下が，多数とりこみでは $50 \%$ が中腸壁を 脱出した。同時に行ったネッタイシマカでは，少数とり こみ $58 \%$ ，多数とりこみで $8 \%$ の脱出率となる（Brenguess and Bain, 1972)。 そしてこの蚊は Mf 密度7.5 11.5/ $\mathrm{mm}^{3}$ でも蚊の死亡率に影響がでなかった（Brenguess and Coz, 1972). 前述 Pichon ら (1974)の「yield が高まる場合」は，この例に基づいている. Omar and Zielke (1978） は，本種の Mf とりこみ平均值が2.6, 対照のネッタイイエカが7.3であった. しかしIII期仔虫 数は，前者が 3 倍も多かったという．前者は cibarial armature でのバリアーの役目が，強力に果たしている からだと説明している，中腸内にとりこむ Mf 数がた とえこのために減っても，そこで生存した Mf は，密 度効果を示さない，ただし，フィールドでは，Wijers and Kiilu(1977) が，ケニアではネッタイイエカの方が III期保有の数，率ともに高いと報告しているし，White （1971）は，タンザニアで，ネッタイイエカの方が劣る， とあい反する報告をしている。また Crans（1973）によ る両種の比較実験では, ネッタイイエカが数, 率ともに 高いが，感染蚊の死亡率も高い。

III期仔虫の産生について影響する要因は，この他にも いくつか知られている. Duxbury ら (1961), Desowitz and Chellappah (1962), Ramachandran (1966) は，若 い蚊よりも古い蚊の方が，III期仔虫保有率，あるいは保 有数が多いことを報告している，前述のように前田・栗 原（1980a）もこれを追試し，保有率は羽化後の日数を 経た蚊の方が高かった。これらの原因は，まだ推定の域 を出ていない.

Omori（1958）は，長崎で越冬前のアカイエカにとり 
こませた Mf が，春には失われていることを見いだし た. 低温が, 仔虫の活性を奪ったことになるが $26 〜 30^{\circ} \mathrm{C}$ ， $80 \sim 90 \% \mathrm{RH}$ の適当条件下でも 18 日余り保存されたネ ッタイシマカから，いるはずのIII期仔虫が見いだされな かった結果が報告されている（Ramachandran, 1966).

異なる時点の Mf とりこみ, すなわち 1 回めの吸血 で Mfをとりこみ，また $2 ， 3$ 回めでもとりこむ現象 は，しばしば観察されている（Krafsar and GarrettJones, 1977 ; Suzuki,1978). Mf を実験的に, 5/ $\mathrm{mm}^{3}$ の宿主から，10日おいてとりこませた成績では，2回と も感染率，Mf の生長曲線， III期仔虫数に大差がない (Meillon ら，1967a).したがって重複した Mf とりこ みを嫌う抗体などの産生はないようだ.

\section{c. III 期仔虫の終宿主移行}

平均6.1匹のIII期仔虫 (W.b.) をもつネッタイイエカ をヒヨコに吸血させ，吸血後に蚊の体内に残っている仔 虫数を調べたところ，3.6匹 $(59 \%)$ がヒヨコに感染さ れることなく，蚊の体内に残留していることがわかっ た. 吸血直後には吻にとどまっている仔虫はいないが， 吸血前に腹部にとどまっていた仔虫が，血液のとりこみ によって胸部へ押し出され, 次回の吸血の際に蚊から宿 主人移行する予備軍となるらしい(Meillon ら，1967b). III期仔虫をもつ蚊が吸血を完了寸る直前に，皮ふに刺し 込まれている fascicle を切りとると吻の仔虫は，皮膚 の表面にはみられても，皮膚組織内にはみられない。し たがって，仔虫は刺し口の吻を奴後に皮膚に侵入す る(Ewert, 1967)。しかし，皮膚内に侵入できないで 死ぬ仔虫も多く， III期総保有数の $45.4 \%$ に達する。 また 1 回の吸血で $32.3 \%$ はお蚊体内にとどまり終宿主へ移 されたものは $22.3 \%$ にずない，吻を刺しても吸血しな かった蚊では，終宿主へ移行したもの3.4\%，蚊体内に 残留しているもの66.7\%となった（Ewert and Ho, 1967 ; Ho and Ewert, 1967).

Zielke（1976）は，同様な実験を，人工膜を通した吸 血時に観察し (W. b.), An. gambiae では79.6\%の仔 虫が体内にとどまり，膜を通りぬけたのは $6.6 \%$ にすぎ なかった，モルモットを吸血させた場合は，体内に残留 している率がやや低くなる。この実験でさらに興味ある のは，より多数の仔虫をもつグループは，吸血を拒否し ていることである。また，砂糖水をガーゼを通じて吸っ た蚊は，0.3〜1.6\%の仔虫を放出したにすぎない，しか しIII期の終宿主への移行は，比率であらわす場合，常に こ5した低率とは思えない，和田ら（1977）は，この比 率は，蚊がもつ仔蜘平均 $1.92 た ゙ と 57 \% ， 1.37 て ゙ は 63$ \%，0.57では $61 \%$ と，保有仔虫数によりちがいがあると いう，概して少数保有では吻に多く集まり，移行の率は
高まると考えられる.フィラリアの種によってもこの差 は明白で, Zielke (1979b) は, B. m., B. p., W. b.の 3 種を比べて, 終宿主へ移行する比率（蚊体内から出た 率×終宿主体内人入った率) は，順に19.6\%，22.2\%， $5 \%$ ，で W. b. は，皮膚表面に残される率は高く，移 行の率が低い. Laurence and Pester (1961) は, ヌ マカ体内の而期仔虫分布を比べているが，W．b. は， Brugia に比べて，頭部にいる率が低いという。バンク ロフトの方が，感染の効率は劣るよらだ。

終宿主の種も，蚊からのIII期移行に影響を及ぼす。 ウゴウヤブカ（B. p.）は，ネコを吸血するときの方が， マウスに対するよりも，早期に(吸血開始後 5 秒で $57 \%$ ), かつ全体ででも $91.35 \%$ と多数を移行させるが，マウス に移行したのは73.98\%と少なかった（Ho and Lavoipierre, 1975). 感染に際しては，仔虫のIII期までの死 亡率に，さらに終宿主移行時のロスを考慮せねばならな W.

\section{3. 伝播の実龍調查}

\section{a. 蚊の生存率}

Rozeboom ら (1968) は, カルカッタの W. b. 流行 地で，ネッタイイエカの Mf 保有数平均值と， III期仔 虫保有数平均值を求め, 自然条件下で HER は0.053 と 算出した，彼らは蚊の日死亡率が $25 \%$ と報告しているの で，10日間の蚊生存率は0.056と計算される。したがっ $\tau$ yield $10.053 \times 0.056=2.96 \%$, 仔虫数減少の理由 はほとんど蚊の死亡に由来している，と推察される。し かもとくに感染に伴ら高死亡率ではなさそらである。

近年, 蚊の卵栄の 観察と 産卵間隔を 知ることによっ て，蚊群の日死亡率，さらには平均余命を計算できるよ うになった. Laurence (1963) は南インド, Samarawickrema (1967) はスリランカのおのおの W. b. 流 行地で, Mf をとりこんだネッタイイエカの日死亡率を, とりこまなかったものと比べて,いずれもほぼ20\%で, 感 染蚊がとくに死にやすいといら証拠はないとしている. Krafsar and Garrett-Jones(1977) もアフリカで $A n$. gambiae が，最初の吸血に際して Mf をとりこんだと 仮定して，保有している仔虫の各ステージの数は， Mf とりこみ後の日数にかかわりなく一定で減少を示さな い，また算出された蚊の日死亡率も感染・非感染蚊とも 16.4\%前後とほぼ等しいことから，Mf とりこみの影響 を否定している，われわれは，まだ十分な証拠をもって いるわけではないが，流行地で蚊は，Mf のとりこみに よって生存率に影響を受けることはあまりないのではな いか.

Abdulcader and Sasa (1966) はスリランカで， 3 年 


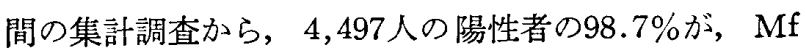
密度 $5 / \mathrm{mm}^{3}$ 以下であり，而期保有蚊総計 $277 匹 の 98.6 \%$ が，III期保有数 14 以下であった. Mf 5 以下の人を吸血 した蚊の Mf とりこみ数は15以下と仮定すると，良く 一致する比率で, 高密度の保虫者から吸血した蚊もとく に高い死亡率を示さなかったと思われる．同じ土地で, Samarawickrema and Laurence (1978) は,さらに子 細に解析し，Mf とりこみ数の平均值が10.3，しかし31 以上とりこんだ蚊は，13.3\%いた．III期保有数の平均值 が2.6（HER が0.25）だが，31以上保有しているもの はゼロ四で，16以上保有が $2.5 \%$ いた，室内実験の結果 もあわ出, Mf 平均值10.3の半数は胸筋へ移行できずに 死に，さらにその半数は胸筋内で生育をできず 2.6 とい う平均值になる。しかし胸㳙内での半減は仔虫自体の死 といらよりは，高密度にとりこんだ蚊が死んだために， 平均值を半減させられたとみている。

Wharton (1962) は Mansonia (B. m.) で, I, II, III期別に保虫数の頻度分布を示している．I期は平均 6.1，I期4.7で，ともに40以上の仔虫をもつ蚊もいる. III

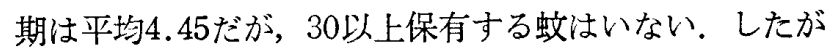
って減少は,多数とりこみ蚊の死または, その仔虫の密度 効果によるところが大と推察される.この場合の HER は0.72と著しく高い.

\section{b. 伝播レベルの数量的表現}

上述のような報告で推察するに, フィラリア流行地で は終宿主の Mf 保有状況が一定の条件下では, 媒介蚊 の生存率が伝播の程度の尺度として重要な役割りをもっ ているといえよう. Wada and Omori (1978) が，トウ ゴウヤブカとアカイエカの伝播効率を, 蚊体内で仔虫が III期に到達して以降の時点における蚊の平均余命で比 較しているのがその例である. マラリアではすでに, Macdonald, Garrett-Jones らにより，蚊の日生存率と 人吸血密度を主たる係数として Basic reproduction rate あるいはVectorial capacity という名の，伝播を 測る数式，あるいは近々発生するであろう患者数を予测 する式が導き出され(栗原, 1971紹介), 近年 Molineaux (1978，1979)が，熱带熱マラリア流行地で予測して，よ く適中し評価を高めた。 この数式でえられる值は，一人 の患者から媒介蚊を通じてえられるであろら二次感染者 の数で，伝播の強さを明確に示すものた．

ところがこの式をフィラリアの伝播に適用するために は，いくつかの前提条件の検討が必要である. その一つ は, 病原体をとりこんだ媒介蚊の生存率が, 正常の蚊と 変わりないか否かである。既述のように, この点, 明確 な結論をえていない，また，終宿主の末梢血に Mf が 出現するまでに何回の感染を必要とするかが未解決であ
る.たとえば Zielke (1977a) は計2,464の而期仔虫(B. m.) をもつと推定される2,250匹のネッタイシマカを, 22 頭のスナネズミから自由に吸血させ，その 4 か月後に 剖検して B. m. 成虫の回収を試みたところ, 回収数 88 (3.5\%) で，しかも2頭は感染をしていなかった.した がってこの数式は，今のところフィラリア症では，新患 者数の予测には使えず，単に伝播の動向を示唆する相対 評価の指標としての価値をもつといえよう.

しかし適切な係数が加わわれば，この式はフィラリア の伝播力を示すものとなるだろう。そのための試みとし て，たとえばWebber (1977) は, Hairston and Meillon (1968) の後述する推定值 $(15,500$ 匹の III期保有 蚊に刺されると Mf 保有者になる) を係数に加えて， 試算している。 また, Bryan and Southgate (1976) は，西サモアの島で一日に生産されるであろうM期仔虫 数で算出するべく，Mf 保有者数， III期仔虫数平均値等 を係数に加えている.

相対的に伝播程度を評洒しよらといら試みは，すでに いくつか知られている。これらは，比較的短期間に解答 が求められ，その要因は，限ら机た人員でカバーするこ とができ，なおかつ伝播の実体に迫る意味のあるもので ありたい. WHO (1974) は，この研究を進めるべき要 因を 5 項目に区分列記し，さらに Sasa (1976) が，こ れを改良し解説を加えたが，さらにその一部を改めて， 次のような項目が伝播に関与する要因と考えている。

(1) 終宿主に関与して

a. 終宿主体内でのフィラリアの成長

1. 寄生した仔出の生長率，2， Mf を産むにい たる個体の比率，3．Mf 産出継続期間

b . 終宿主集団の伝播に関与する条件

1. Mf 陽性率, 2. Mf 密度分布, 3. 蚊吸血 相当量中の Mf 密度

(2) 媒介昆虫に関与して

a. Mf のとりこみ

1.とりこみ数の変異幅, 2 . 吸血時刻と末梢血 中 Mf 出現時刻の適合性

b. 昆虫体内での仔虫生長と終宿主移行

1. 生長所要日数と仔虫生存率, 2 . 昆出の生存 率, 3 . 吸血時の終宿主への移行率

c . 昆虫集団の生態的要因

1. 1 終宿主の年閒刺咬数，2. II 期保有率と, 平均保有数, 3. III期保有昆虫の年間刺咬数, 4 . 人嗜好性と吸血間隔

これらの要因を数で表していくと，伝播の状況を装現 できるかもしれない. 現に, Beye and Gurian (1960) は，1匹の Mf が，成虫に青つ確率を算出することを 


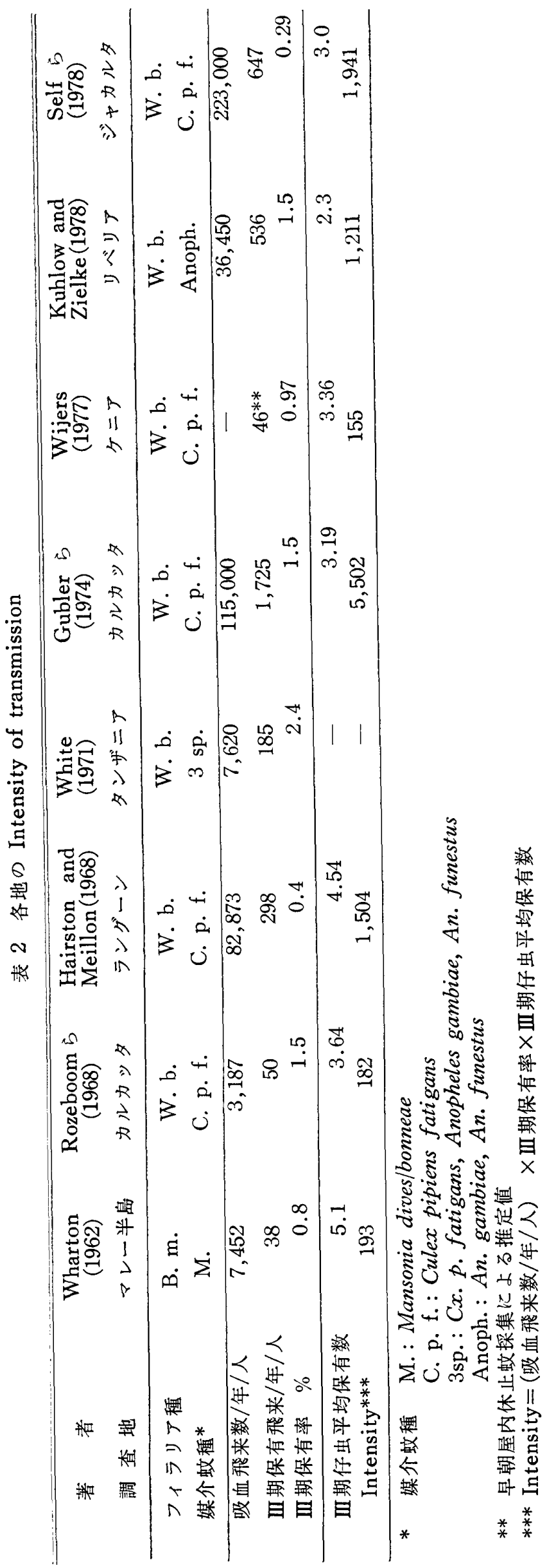

試みた。がここの式はあまりに複雑な要因がとりこめら れ，実際に野外調查で用いられるとは思えない，その 後, 伝播の実態を簡易に把握するための指標がいくつか 報告された. Wharton (1962) は Intensity of transmission として 1 人が一定期間に「何匹の而期保有蚊に 刺されるか」を算出しマレー半島流行地 (B. m.) で, 1 年に 38 匹と推定した. WHO (1962) は, potential transmission index として，人おとりによる採集数と， 仔虫保有蚊率の積を，また，Meillon ら(1967b)は，1時 間 1 人当たり吸血蚊数，その中の経産蚊率，経産蚊中の III期保有蚊率の 3 項の積を, Risk of infection index として示した.

この中で Whartonの方式は, Hairston and Meillon (1968）がラングーン（W．b.）で計算し，298匹と求め た。この際, 年平均 Mf 陽転者数等を考慮し, Efficiency of transmission として，1 人が15,500回而期保有蚊に 刺されると Mf 陽性者になると推定した. その後 Gubler and Bhattacharya (1974) は, カルカッタで, Wijers (1977) がアフリカの, それぞれ Intensity of transmission を算出している。これらの各地の成續を 表 2 にまとめているが，流行地ごとでかなり変異幅が大 きい(表 $2 の$ Intensity は，表の説明に基づく).

伝播防止の作業は，この Intensity を低下させること が目的となるが，現状ではこれは総合的な目やすとし てなら計算する意義もあろう．もしも集団駆虫が対策の 主流であるなら，媒介蚊の監視すべき項目には，而期保 有率を入れるとともに，蚊の Mf とりこみ状態も調查 すべき指標となる. Samarawickrema and Laurence (1978) は，蚊の Mf 保有率が，人の Mf 保有率より 高く，検血が不完全なのではないかと指摘している．ま た媒介蚊対策を進めるなら, 人吸血密度と, 蚊の生存率 の 2 点が重要な評価規準となるだろう．幸いにヒトのフ イラリア媒介蚊の多くが，高い人吸血咾好性をもってい るが，人獣共通のフィラリア症の場合は，吸血源調查が 必要な点検事項となるだろう. 限られた人員, 予算で進 める媒介蚊の監視態勢では, 調查項目をできるだけ絞っ ていきたいが，たとえば川期保有率の值は，集団駆虫の 後などでは，1,000匹調べても1匹いるか否か（Suzuki and Sone，1973）といら低率になる。したがって必ず しも，こだわる数值ではなく，より能率のよい評価規淮 を求めていきたい.

本稿作製にあたり佐々学先生の御指導をいただいた。 文献の一部は, 吉村堅太郎先生(順天堂大), 神谷正男先 生(北大), 斉藤一三先生(横浜市大) から貸与された。ま た, 日米医学協力計画寄生虫病部会の御援助をいただい た. 


\section{引用文献}

Abdulcader, M. H. M. and M. Sasa (1966): Epidemiology and control of bancroftian filariasis in Ceylon. Jap. J. Exp. Med., 36 : 609646.

Benach, J. L. and W. C. Crans (1975) : Differential susceptibility of Culex territans and Aedes triseriatus to Foleyella flexicanda. J. Med. Entomol., 12 : 209-213.

Beye, H. K. and J. Gurian (1960) : The epidemiology and dynamics of transmission of $W u$ chereria bancrofti and Brugia malayi. Ind. $J$. Malariol., 14 : 415-440.

Brengues, J. and J. Coz (1972) : Receptivite comparee des trois especes du complexe Anopheles gambiae presentes en Afrique de l'Ouest visavis de Wuchereria bancrofti. Cah. ORSTOM, Ser. Entomol. Med Parasitol., 10 : 207-215.

Brenques, J. and O. Bain (1972) : Passage des microfilariae de comples Wuchereria bancroftiAnopheles gambiae A, W. bancrofti-Aedes aegypti et Setaria labiatopapillosa-Ae. aegypti. Cah. ORSTOM. Ser. Entomol. Med. Parasitol., $10: 235-250$.

Briegel, H., A. O. Lea and M. J. Klowden (1979) : Haemoglobinometry as a method for measuring blood meal sizes of mosquitoes. $J$. Med. Entomol., 15 : 235-238.

Bryan, J. H., P. Oothuman, B. J. Andrews and P. B. McGreevy (1974a) : Effects of pharyngeal armature of mosquitoes on microfilariae of Brugia pahangi. Trans. R. Soc. Trop. Med. Hyg., 68 : 14.

Bryan, J. H., P. B. McGreevy, P. Oothuman and B. J. Andrews (1974b) : Effects of the pharyngo-cibarial armature of mosquitoes on microfilariae. 3rd. Int. Cong. Parasitol., 2 : 610-611.

Bryan, J. H. and B. A. Southgate (1976) : Some observations on filariasis in Western Samoa after mass administration of diethylcarbamazine. Trans. R. Soc. Trop. Med. Hyg., 70 : 39-48.

Burren, C. H. (1972) : The behaviour of Brugia malayi microfilaria in experimentally infected cats. Ann. Trop. Med. Parasitol., 66 : 235-242.

Carme, B. and J. Laigret (1979) : Longevity of Wuchereria bancrofti var. Pacifica and mosquito infection acquired from a patient with low level parasitaemia. Am. J. Trop. Med. Hyg., $28: 53-59$.

Christensen, B. M. (1978) : Dirofilaria immitis; effect on the longevity of Aedes trivittatus. Exp. Parasitol., 44 : 116-123.

Coluzzi, M. and R. Trabucci (1968) : Importanza dell'armatura bucco-faringea in Anopheles e
Culex in relazion alle infezion con Dirofilaria. Parassitologia, 10 : 47-59.

Crans, W. J. (1973) : Experimental infection of Anopheles gambiae and Culex pipiens fatigans with Wuchereria bancrofti in coastal east Africa. J. Med. Entomol., 10 : 189-193.

Denham, D. A., I. T. Dennis, G. S. Ponnuduri, G. S. Nelson and G. Frances (1971) : Comparison of a counting chamber and thick smear methods of counting microfilaria. Trans. $R$. Soc. Trop. Med. Hyg., $65: 521-526$.

Desowitz, R. S. and W. T. Chellappa (1962) : The transmission of Brugia species through Culex pipines fatigans. The effect of age and prior non-infected blood meals on the infection rate. Trans. R. Soc. Trop. Med. Hyg., 56 : 121-125.

Duxbury, R. E., A. P. Moon and E. H. Sadum (1961) : Susceptibility and resistance of Anopheles quadrimaculatus to Dirofilaria uniformis. J. Parasitol. 47 : 687-691.

Esslinger, J. H. (1962) : Behaviour of microfilariae of Brugia pahangi in Anopheles quadrimaculatus. Am. J. Trop. Med. Hyg., 11 : 749-758.

Ewert, A. (1967): Studies on the transfer of infective Brugia pahangi larvae from vector mosquito to the mammalian host. Trans. $R$. Soc. Trop. Med. Hyg., 61 : 110-113.

Ewert, A. and B. C. Ho (1967): The fate of Brugia pahangi larvae immediately after feeding by infective vector mosquitoes. Trans. R. Soc. Trop. Med. Hyg., 61: 659-662.

Gubler, D. J., T. S. Innui, H. R. Block and N. C. Bhattacharya (1973): Comparisons of microfilaria density in blood sampled by finger prick, venipuncture and ingestion by mosquitoes. Am. J. Trop. Med. Hyg., 22 : 174-178.

Gubler, D. J. and N. C. Bhattacharya (1974) : A quantitative approach to the study of bancroftian filairiasis. WHO/FIL/74., 129 (mimeographed).

Hairston, N. G. and B. de Meillon (1968): On the inefficiency of transmission of Wuchereria bancrofti from mosquito to human host. Bull. Wld Hlth Org., 38 : 935-941.

Hawking, F. and M. Worms (1961) : Transmission of filarioid nematodes. Ann. Rer. Entomol., 6 : 413-432.

Ho, B. C. and A. Ewert (1967): Experimental transmission of filarial larvae in relation to feeding behaviour of the mosquito vectors. Trans. R. Soc. Trop. Med. Hyg., 61 : 663-666.

Ho, B. C. and M. M. Lavoipierre (1975) : Studies on filairiasis. IV. The rate of escape of the third-stage larvae of Brugia pahangi from the mouth parts of Aedes togoi during the 
blood meal. J. Helminthol., $49: 65-72$.

Jordan, P. and K. D. Goatly (1962) : Bancroftian filariasis in Tanganyika: a quantitive study of the uptake, fate, and development of microfilariae of Wuchereria bancrofti in Culex pipiens fatigans. Am. Trop. Med. Parasitol., 56 : 173-187.

Kartman, L. (1954) : Suggestions concerning an index of experimental filaria infection in Mosquitoes. Am. J. Trop. Med. Hyg., 3 : 329337.

Kershwa, W. E., M. M. J. Lavoipierre and T. A. Chalmers (1953) : Studies on the intake of microfilariae by their insect vectors, their survival and their effect on the survival of their vectors. 1. Dirofilaria immitis and Aedes aegypti. Ann. Trop. Med. Parasitol., $47: 207-224$.

Krafsar, E. S. and C. Garrett-Jones (1977) : The survival in nature of Wuchereria infected Anopheles funestus Giles in north-eastern Tanzania. Trans. R. Soc. Trop. Med. Hyg., $71: 155-160$.

Kuhlow, F. and E. Zielke (1978) : Dynamics and intensity of Wuchereria bancrofti transmission in the savannah and forest regions of Liberia. Tropenmed. Parasitol., 29 : 371-381.

栗原 毅 (1971)：昆虫学が蚊媒介病の疫学に果たす 役割り。 vectorial capacity を主として。熱帯, 5 : 227-233.

Laurence, B. R. (1963) : Natural mortality in two filarial vectors. Bull. Wld Hlth Org., 28 : 229-234.

Laurence, B. R. and F. R. N. Pester (1961): The behaviour and development of Brugia patei in a mosquito host, Mansonia uniformis. J. Helminthol., 35 : 285-300.

前田龍一郎, 栗原 毅 (1980a)：トゥゴウヤブカ Aedes togoi の吸血時日令がマレー系状虫の伝播 に及ぼす影響. 衛生動物, 31:277-281.

前田龍一郎, 梠原 毅 (1980b)：蚊の吸血量とミク ロフィラリア摂取数の個体別測定法. 衛生動物, 31 : 299-302.

McGreevy, P. B., J. H. Bryan, P. Oothuman and N. Kolstrup (1978) : The lethal effects of the cibarial and pharyngeal armatures of mosquitoes on microfilariae. Trans. R. Soc. Trop. Med. Hyg., 72:361-368.

Meillon, B. de., S. Hayashi and A. Sebastian (1967a): Infection and reinfection of Culex pipiens fatigans with Wuchereria bancrofti and the loss of mature larvae in blood feeding. Bull. Wld Hlth Org., $36: 81-90$.

Meillon, B. de., B. Grab and A.Sebastian (1967b) : Evaluation of Wuchereria bancrofti infection in Culex pipiens fatigans in Rangoon, Burma. Bull. Wld Hlth Org., 36 : 91-100.
Molineaux, L. (1978) : Entcmological parameters in the epidemiology and control of vector-borne disease. In Medical Entomology Centenary, pp. 100-105, R. Soc. Trop. Med. Hyg., London. Molineaux, L., G. R. Shidrawi, J. L. Clarke, J. R. Boulzaguest and T. R. Ashkar (1979): Assessment of insecticidal impact on the malaria mosquitoes vectorial capacity, from data on the man-biting rate and age-composition. Bull. Wld Hlth Org., 57 : 265-274.

中村義清(1964)：バンクロフト系状虫症の伝搬に関 わるトウゴウヤブカの役割に関する実験的研究.

1. 長崎大風土病紀要, $6: 25-33$.

Nathan, M. B. and C. Raccurt (1979) : Higher concentrations of microfilariae in capillary blood from the ear lobe than from the finger in Wuchereria bancrofti and Mansonella ozzani. Trans. R. Soc. Trop. Med. Hyg., 73 : 455-457.

Obiamiwe, B. A. (1977a): The fate of ingested Burgia pahangi microfilariae in susceptible and refractory strains of Culex pipiens and Aedes aegypti. Ann. Trop, Med. Parasitol., $71: 375-377$.

Obiamiwe, B. A. (1977b) : Relationship between microfilaria density, the number of microfilariae ingested by mosquitoes and the proportion of mosquitoes with larvae. Ann. Trop. Med. Parasitol., 71 : 491-500.

Oda, T. and Y. Wada (1980) : Exsheatment and migration of microfilariae of Brugia malayi (Che-ju strain) in mosquitoes. Trop. Med., 22 : 27-33.

Omar, M. S. and E. Zielke (1978) : Abortive development of Wuchereria bancrofti in a West African strain of Culex pipiens fatigans. Tropenmed. Parasitol., 29 : 364-370.

Omori, N. (1958) : Experimental studies on the role of the house mosquito, Culex pipiens pallens in the transmission of bancroftian filaria. 3. Duration of life of filariae in mosquitoes exposed to winter temperature. Yokohama Med. Bull., 9 : 382-390.

大森南三郎 (1958)：バンクロフト系状虫症の伝搬に 関するアカイエカの役割に関する実験的研究. 2 . 人末梢血流中に扔ける Mf の分布様式について。 長崎医学会誌, 33: 1045-1053.

Owen, R.R.(1978) : The exsheahtment and migration of Brugia pahangi microfilariae in mosquitoes of the Aedes scutellaris species complex. Ann. Trop. Med. Parasitol., 72: 567-571.

Pacheco, G., M. J. Atkins and J. Gurian (1972) : Qualification of infection of ticks with Dipetalonema viteae. J. Parasitol., 58 : 275-278.

Pichon, G., G. Perrault and J. Laigret (1974) : Rendement parasitaire chez les vecteurs de 
felarioses. Bull. Wld Hlth Org., 51 : 517-524.

Ramachandran, C. P. (1966) : Biological capacities in the transmission of Brugia malayi by Aedes aegypti in the laboratory. J. Med. Entomol., 3 : 239-252.

Ramachandran, C. P. and M. A. Zaini (1967): Studies on the transmission of subperiodic Brugia malayi by Aedes (Finlya) togoi in the laboratory. I . Med. J. Malaya, $22: 136$ 144.

Ramachandran, C. P. and M. A. Zaini (1968) : Studies on the transmission of subperiodic Brugia malayi by Aedes (Finlaya) togoi in the laboratory. II. Med. J. Malaya, $22: 198-$ 203.

Rosen, L. (1955) : Observations on the epidemiology of human filariasis in French Oceania. Am. J. Hyg., 61 : 219-248.

Roseboom, L. E., N. C. Bhattacharya and S. K. Gilotra (1968) : Observations on the transmission of filariasis in urban Calcutta. Am. J. Epidemiol., 87 : 616-632.

Samarawickrema, W. A. (1967) : A study of the age composition of natural population of Culex pipiens fatigans Wied. in relation to the transmission to the transmission of filariasis due to Wuchereria bancrofti in Ceylon. Bull. Wld Hlth Org., 37 : 117-137.

Samarawickrema, W. A., and B. R. Laurence (1978) : Loss of filarial larvae in a natural mosquito population. Ann. Trop. Med. Parasitol., 72 : 561-565.

Samarawickrema, W. A., F. Sone, K. Ichimori and R. F. Cummings (1979) : Filariasis in Western Samoa. I . Transmission studies of Aedes (Stegomyia) polynesiensis (Marks) and Ae. ( $F$.) samoanus on carriers with different levels of microfilararemia of Wuchereria bancrofti. WHO/VBC/79. 751 (mimeographed).

Sasa, M. (1976) : Human filariasis; a global survey of epidemiology and control, 819pp., Univ. of Tokyo Press, Tokyo.

Schmid, W. D. and E. J. Robinson, Jr. (1972) : The pattern of a host-parasite distribution. $J$. Parasitol., 58 : 907-910.

Self, L. S., S. Usman, H. Sajidiman, F. Partono, M. J. Nelson, C. P. Pant, T. Suzuki and H. Mechfudin (1978) : A multidisciplinary study on bancroftian filariasis in Jakarta. Trans. $R$. Soc. Trop. Med. Hyg., 72 : 581-587.

Suzuki, T. (1978) : Preliminary studies on blood meal interval of Aedes polynesiensis in the field. Jap. J. Sanit. Zool., 29 : 169-174.

Suzuki, T. and F. Sone (1973) : Filariae infection in vector mosquitoes after mass drug administration in Western Samoa. WHOV VBC/ 73. 117 (mimeographed).
田中寛，千葉日美，田中英文(1963)：コトンラッ ト糸状虫のミクロフィラリアの中間宿主イエダニ による吸入量の定量的観察. 寄生虫誌, 12 : 191195.

和田芳武，韵岡正敏，白坂昭子(1977)：3 種采状出 の伝搬過程の量的観察。奇生虫誌，26:101-112.

Wada, Y. and N. Omori (1978) : Comparision of the transmission efficiency between two human filaria parasites. Res. Filaria Shistsomiasis, $3: 145-150$.

Webber, R. H. (1977) : The natural decline of Wuchereria bancrofti infection in a vector control situation in the Solomon Islands. Trans. R. Soc. Trop. Med. Hyg., 71 : 396-400.

Wharton, R. H. (1957a) : Studies on filariasis in Malaya: Observations on the development of Wuchereria malayi in Mansonia (M.) longipalpis. Ann. Trop. Med. Parasitol., 51 : 278296.

Wharton, R. H. (1957b) : Studies on filariasis in Malaya: The efficiency of Mansonia long $i$ palpis as an experimental vector of Wuchereria malayi. Ann. Trop. Med. Parasitol., 51 : 422439.

Wharton, R. H. (1962) : The biology of Mansonia mosquitoes in relation to the transmission of filariasis in Malaya. Bull. Inst. Med. Res. Malaya, 11 : 114pp.

White, G. B. (1971) : Studies on transmission of bancroftian filariasis in North-eastern Tanzania, Trans. R. Soc. Trop. Med. Hyg., 65 : 819-829.

WHO (1962) : Expert Committee on filariasis. Wld Hlth Org., Tech. Rep. Ser. 233, 49pp.

WHO (1974) : Expert Committee on filariasis. Third report. Wld Hlth Org., Tech. Rep. Ser. 542, 54pp.

Wijers, D. J. B. (1977) : Bancroftian filariasis in Kenya. IV. Disease distribution and transmission dynamics. Ann. Trop. Med. Parasitol., 71: 451-463.

Wijers, D. J. B. and G. Kiilu (1977) : Bancroftian filariasis in Kenya. III. Entomological investigations in Mambrui, a small coastal town, and Jaribuni, a rural area more inland. Ann. Trop. Med. Parasitol., 71 : 347-359.

山本 久 (1964)：フィラリア症の疫学的研究 (2). 奄 美大島に扝汸るバンクロフト糸状虫の蚊体内発去 条件に関卞る研究．衛生動物，15:245-257.

Zielke, E. (1976) : Studies on quantitative aspects of the transmission of Wuchereria bancrofti. Tropenmed. Parasitol., 27 : 160-164.

Zielke, E. (1979a) : Quantitative aspects of the development of mosquito transmitted Brugia malayi and $B$. pahangi and their distribution in jirds. Tropenmed. Parasitol., $30: 163-169$.

Zielke, E. (1979b) : Comparative studies on the 
transmission rate of Wuchereria and Brugia. Trans. R. Soc. Trop. Med. Hyg., 73 : 329-330.

\section{Summary}

This paper reviews information on quantitative aspects of filaria larval populations in the mosquito phase. One aim is to clarify the conditions necessary for efficient filarial transmission by mosquitoes during maintenance in the laboratory, including the requirement of suitable microfilaraemia in the host animal. Secondly, attention is given to ways of analysing the dynamics of filaria transmission in endemic areas.

In general, the rate of mosquitoes becoming infected with microfilariae is proportional to the density of microfilaraemia in the host; the actual numbers of microfilariae ingested also increase in proportion to the microfilaria density. Numbers of ingested microfilariae may not be as expected from theoretical calcaulations based on two parameters: "microfilaria density in the host" and "quantity of blood ingested by mosquito." Some papers have reported mosquitoes to ingest fewer or more microfilariae than expected on the basis of these parameters. However, other studies have found that the mean number of ingested microfilariae is more or less close to what would be expected.

Some possible explanations are discussed in order to account for the observed variations in the numbers of microfilariae ingested by mosquitoes. Such differences have been found between mosquito species, between strains within the same species, and between mosquitoes of different ages. Microfilaria intake is not so well correlated with the quantity of blood ingested. Defecation or discharge of blood from the anus of engorged mosquitoes may affect the number of microfilariae ingested and retained. In some species of mosquitoes oesophageal armatures may kill some of the ingested microfilariae. Density variations of microfilariae in different regions of the host skin must also be monitored carefully in relation to the feeding-sites of female mosquitoes.

Several authors have shown that only limited numbers of filarial larvae develop to the third (infective) stage in each mosquito, despite the ingestion of more microfilariae by some individual female mosquitoes. Two basic factors are considered to account for the failure of some microfilariae to grow successfully. Either the infected mosquitoes may die, or else there may be mortality of the filarial larvae themselves. Under laboratory conditions, it seems that mosquito mortality is the greater influence. Additionally, some of the infective larvae may fail to be transmitted when the vector feeds again on a vertebrate host. This is due partly to third stage larvae remaining within the mosquito, and partly to failure to penetrate the host's skin by those infective larvae which escape successfully from the vector.

On the basis of papers quoted here, it is suspected that in endemic areas the parasite yield is less than $10 \%$ of the total microfilariae ingested, with a few exceptions such as Brugian filariae ingested by Mansonia mosquitoes. This reduction of parasite yield is largely due to the mortality of mosquitoes during the incubation period for filarial larvae. Mosquito longevity, whether or not specimens have become infected with filariae, is therefore a most important component of vector capacity under field conditions. Transmission efficiency is expressed in terms of several indices, proposed and discussed here. For continuing epidemiological surveillance of filariasis, it is considered necessary to minimize the number of factors to be observed for measurement of transmission efficiency, in order to economize the use of man-power and technical resources for field operations. 